\title{
Foreign-owned companies in countries with an unstable economy: The case of the automotive industry in Russia
}

\author{
Vladislav Spitsin \\ National Research Tomsk Polytechnic University \\ Tomsk, Russia \\ Tomsk State University of Control Systems and Radioelectronics \\ Tomsk, Russia \\ spitsin_vv@mail.ru
}

\author{
Alexander Mikhalchuk \\ National Research Tomsk Polytechnic University \\ Tomsk, Russia \\ aamib@tpu.ru \\ Lubov Spitsina \\ National Research Tomsk Polytechnic University \\ Tomsk, Russia \\ s_luba_07@mail.ru
}

\section{Darko B. Vukovic}

National Research University Higher School of Economics,

St. Petersburg, Russia

vdarko@hotmail.rs

Abstract. This paper analyses the development patterns for the foreign-owned enterprises in countries with an unstable economy. The object of research refers on enterprises in foreign (FO), joint (JO) and Russian (RO) ownership producing cars and auto components in the territory of the Russian Federation. The research is based on the application of method of regression analysis of panel data for analysing the financial performance of the enterprises. We have identified that foreign-owned enterprises react more sharply on crises and changes in exchange rates. The depreciation of the ruble has a particularly negative impact on the profitability of foreign-owned enterprises. The crisis periods have a strong negative impact on the revenue of enterprises by all forms of ownership.

Keywords: foreign direct investment (FDI), automotive industry, economic sanctions, foreign and joint ownership, Russia.

JEL Classification: F21, Q3, Q14 


\section{INTRODUCTION}

Automobile industry is one of the most important branches of any economy. It is characterized by sufficiently high employment rate, science intensity and obvious innovative results.

It influences the development of many related industries and the products of which are used in the production of cars, such as: metallurgy, automotive electronics, oil production and processing, road construction, etc. Development of the automotive industry is always related to political and economic processes. At the same time, the technological backwardness of this industry in developing countries leads to the establishment of foreign and joint enterprises on their territories and this can cause both positive and negative effects on their economies.

The problems of foreign and joint enterprises' creation and development have been actively studied by international and Russian economists. The Eurostat (2015) database in its section "Structural business statistics" has data on "Foreign controlled EU enterprises", which include indicators, characterizing the number of personnel, performance, added value, etc. However, indices on investment activity, investments in buildings and equipment are missing in this database. Some of the researchers (Anwar and Sun, 2015; You and Solomon, 2015; Chayawisan, 2015; Szkorupová, 2015; Sun et al., 2015) examined the impact of foreign direct investments (FDI) on the structure of capital and investment in domestic firms and their economic growth by ownership forms.

According to the one number of authors, FDI affects human capital of staff, their labour productivity and salary at both foreign and domestic enterprises (Chen, 2011; Grubisic et al., 2011; Chen et al., 2011; Dachs \& Peters, 2014; Kochetkov et al., 2017). They also noted the significant role of foreign firms in innovation import of national manufacturing (Girma et al., 2009; Murakami, 2007).

Some scientists confirmed the presence of positive effects from FDI on investments of domestic firms, revealed for some countries and separate industries (Chayawisan, 2015; You \& Solomon, 2015). "The most positive effect of foreign firms" in the cases of monopolized sectors, investments have been marked by Buckley et al. (2007) and Girma et al. (2009). Similar effects have been identified for high-tech industries (Chayawisan, 2015; You and Solomon, 2015). Anwar and Sun (2015) confirmed the role of Chinese government policy on stimulation of foreign firms operating in labour-intensive industries. Villarreal and Sakamoto (2011) made an assumption that foreign investments in human capital are more preferential in labour-intensive industries. At the same time, some scientists have not identified the hypothesis about the positive impact of foreign firms' investment and production activity on domestic markets for the whole economy (Murakami, 2007; Girma et al., 2009), or for separate sectors of (Buckley et al., 2007; Basti et al., 2015; Szkorupová, 2015).

Many researchers are studying the performance rates of separate firms. Bearing in mind this, mathematical and statistical methods of data analysis are used at the level of individual firms. Creation and development of enterprises with foreign and joint forms of property have been studied in many research (Zhang \& van den Daniel, 2000; Lynch, 2002; Firat \& Li, 2016; Pavlinek, 2017; Godlewska-Majkowska \& Komor, 2017; Fava \& Luminita, 2017). In these research, the authors described the situation within the automotive industries of European countries along with the dynamics of their indicators' development (Pavlinek, 2017; Godlewska-Majkowska and Komor, 2017) as well as the FDIs' role in these industries' development (Zhang and van den Daniel, 2000; Lynch, 2002; Firat and Li, 2016; Godlewska-Fava and Luminita, 2017). The significant share of the related research is devoted to FDI factors and dynamics assessments in developed countries (like Germany and Japan) and in developing countries (as China and Taiwan). Complex analysis of Russian automotive industry's development since 1990 and the related state policy has been carried out by Baronina (2016). 
Current world trends in the development of the automotive industry have been investigated by (Chan \& Hoshgiyafeh, 2014; Afanasyev, 2014; Podhalyuzina, 2015; Ovchinnikova \& Karpova, 2015; Volgina \& Vozmilova, 2015; Efremova, 2015). These researchers noted the following features in the development of the automotive industry.

1. It was substantial change in the production structure over the 40-year period, from 1971 to 2014. The share of North America and Europe in the global production of cars fell by 2 times, from $46 \%$ to $23 \%$. On the contrary, there was an increase in production in Asian countries, from 16\% to 53\% (Volgina and Vozmilova, 2015). Europe, despite its declining share in the total car production, remains the export leader; providing $48 \%$ of the world car exports. Because of this, European enterprises are characterized by the greatest competitiveness and the most active expansion into foreign markets.

2. Asian countries have applied different models of production organization in their automotive industries. China has focused primarily on protecting its domestic market and developing national automotive production through the establishment of joint enterprises with the world leaders in the production of cars; and then through the creation of national productions. China's capacious of domestic market $\theta$ is more than $20 \mathrm{mln}$ cars per year $(21.1 \mathrm{mln}$ cars in 2015, see more on https://www.zr.ru/content/news/840596-itogi-prodazh-avtomobilej-v-kitae-v-2015-godu-gudbajamerika/) is the priority for Chinese automobile factories at present and it is holding back the expansion of this country to foreign markets. China almost completely satisfies the demand of its domestic market through national and joint productions (having produced $19 \mathrm{mln}$ cars in 2014) but has a small share (approximately 3,4\%) in the global car exports (Volgina and Vozmilova, 2015, pp. 42-44). Another model is demonstrated by India, which has initially hindered foreign investment and then, on the contrary, turned out to be dependent on foreign producers. At present, enterprises with the foreign form of ownership prevail in this country (Chan \& Hoshgiyafeh, 2014; Afanasyev, 2014).

3. What are current trends in the development of the automotive industry? Enterprises are switching from large-scale production of a small number of car models to a small-scale production of a wide range of vehicles. We can observe the increasing level of competition along with the decreasing concentration of the market and the share of the largest enterprises in the markets. Production of cars is characterized by high science-intensive and the active introduction of innovations and new technologies (Ovchinnikova \& Karpova, 2015).

4. The automotive industry market of Russia undoubtedly attracts foreign manufacturers. Despite the crisis period, in 2017, the automotive market of Russia ranks 5th in Europe, and in certain months Russia rises to second place in car sales (Chuprov, 2018). The following features of the automotive industry development in Russia should be noted:

- introduction of the industrial assembly regime back in 2005 created favourable conditions for the creation and development of foreign and joint productions in Russia;

- effects for Russian economy from the creation of enterprises with foreign and joint forms of ownership are limited;

- development of the automotive enterprises in Russia was strongly influenced by the crises of 20082009 and then 2014-2015.

Development of the automotive industry in Russia covers the following stages:

- 1996 and 1998 - establishment of the first car assembly plants (Akimkina, 2014; Komissarova, 2014; Russian automotive production localization, 2014);

- 2002 - first agreements on the industrial assembly (Akimkina, 2014);

- 2005 - adoption of legislation on the industrial assembly (Bulletin of socio-economic crisis in Russia. Cars market, 2016; Russian automotive production localization, 2014); 
- 2007 - the founding of 4 factories (foreign ownership) to produce cars in Russia (Bulletin of socio-economic crisis in Russia. Cars market, 2016);

- 2008-2009 - the financial and economic crisis, a drastic decrease in production of almost all enterprises in the industry. The state takes measures to mitigate the crisis;

- 2010-2011 - adoption of the following legislative documents: Strategy for the Development of the Automotive Industry in Russia and the Strategy for Innovative Development of Russia until 2020. The former has provided four scenarios for the automotive industry development, and the latter has determined the strategic priorities of innovation development through import and adaptation of advanced foreign technologies and the establishment of joint enterprises (Akimkina, 2014);

- 2011 - tightening of legislation on industrial assembly, which provides for a significant increase in the requirements as to output volume, the degree of production localization; introduction of the requirements on the creation of scientific and research centers on the territory of Russia within 5 years from the date of signing the agreement (Kurganov, 2015);

- 2011-2012 - the conclusion of agreements on the industrial assembly of automotive components begins, which contain requirements on the degree of their localization in Russia (Kurganov, 2015);

- 2012 - Russia's accession to the WTO, in the context of which Russia assumes obligations not to conclude new agreements and to terminate previously concluded agreements in 2018 while reducing import duties (Kurganov, 2015; Pasko, 2014);

- 2014-2016 - the period of political problems, economic sanctions and economic crisis caused by the fall in oil prices, the growth of the USD exchange rate, decrease in the income level and effective demand.

The purpose of our research is to study the development patterns for the foreign-owned enterprises in countries with an unstable economy. After the collapse of the Soviet Union, a number of post-communist countries faced the need for serious economic changes that were accompanied and accompanied by economic instability. These transition countries include the following European countries: Central and Eastern European Economies (Czech Republic, Hungary, Poland, etc.), Commonwealth of the Independent States (Russia, Bela-rus and others), Baltics (Estonia, Latvia, Lithuania). We carry out research on the example of the automotive industry in Russia, because:

- The previous period has contributed to the creation of a significant number of large enterprises in foreign ownership and the transition of some enterprises to joint form of ownership;

- The automotive industry reacts quite sharply to periods of instability, because cars are kind of investment commodity;

- Since 2014 Russia has been experiencing to a certain extent, including the imposition of economic sanctions and political tension, as well as a significant deterioration in the economic conditions and living standards of the population (falling oil prices and the ruble exchange rate).

In this paper we plan to explore the development of enterprises in foreign ownership (FO), and enterprises with a joint form of ownership (JO) in comparison with enterprises in Russian state ownership (RO). The research is based on the application of mathematical methods (methods of regression analysis of panel data) for analysing the financial performance of the enterprises.

The following hypotheses are checked in the course of this research. 
Hypothesis 1: The tightening of the industrial assembly regime in 2011 adversely affected the development of foreign-owned enterprises in Russia.

Hypothesis 2: Crises and the depreciation of the ruble negatively affected the dynamics of indicators at enterprises in the Russian automotive industry for all forms of ownership in 2014-2016.

Hypothesis 3: Foreign-owned enterprises are more affected because of political and economic instability and the depreciation of the ruble.

\section{METHODOLOGY}

The object of research referes on enterprises in foreign (FO), joint $(J O)$ and Russian (RO) ownership producing cars and auto components in the territory of the Russian Federation.

At the macroeconomic level, we will examine the following key indicators (Table 1) in order to characterize the features of the environment and the aggregate results of the development of foreign-owned enterprises in Russia.

Table 1

The main indicators for macroeconomic analysis and the objectives of their study

\begin{tabular}{|l|c|l|}
\hline \multicolumn{1}{|c|}{ Indicators and their abbreviations } & Period & \multicolumn{1}{c|}{ Objectives of the study } \\
\hline $\begin{array}{l}\text { Number of cars produced (CP) } \\
\text { Number of cars sold (CS) }\end{array}$ & $2006-2015$ & Assessment of market trends \\
\hline Aggregated revenue of enterprises (R) & $2006-2015$ & $\begin{array}{l}\text { Estimation of growth rates by types of } \\
\text { ownership }\end{array}$ \\
\cline { 1 - 2 } $\begin{array}{l}\text { Number of cars exported (CE) } \\
\text { Number of imported cars (CI) }\end{array}$ & $2006-2015$ & $\begin{array}{l}\text { Evaluation of positive and negative effects from } \\
\text { the establishment of enterprises in FO }\end{array}$ \\
\cline { 1 - 2 } $\begin{array}{l}\text { The share of imported raw materials in } \\
\text { shipped products (SRM) }\end{array}$ & $2010-2015$ & \\
\hline
\end{tabular}

Source: Authors

Statistical data are obtained from the Federal Statistics Service of Russia (Rosstat, 2017; UniSIS, 2017). For the study of indicators at the enterprise level, we apply the methods of regression analysis of panel data. Data of financial indicators of enterprises are obtained from the Spark and FIRA Information Systems (SPARK, 2017; FIRA 2017). We gathered this information from 2012 to 2016. The sample of enterprises of the automotive industry was formed according to the criterion the revenue in 2012-2016 of at least 100 million rubles annually. All enterprises of the automotive industry that met this criteria were included in the sample (solid sample).

In accordance with this criteria, the following sample of the enterprises were formed:

- 55 enterprises in foreign ownership;

- 25 enterprises in Russian property;

- 225 enterprises in joint ownership;

- In total - 305 enterprises.

We got the panel data on 1525 (305*5) firm-year observations.

After following wide and actual entrepreneurship literature (Vaicondam and Ramakrishnan, 2017; Chatterjee, 2012; Habrosh, 2017) we choose the net profitability of assets as the dependent variable. This indicator characterizes the profitability and efficiency of enterprises. As independent variables, we used the following (Vaicondam, Ramakrishnan, 2017; Chatterjee, 2012; Habrosh, 2017):

- control variables (size of the enterprise calculated as natural logarithm of revenue; fixed assets share calculated as share of fixed assets in assets, current liquidity ratio), 
- year dummies (dummy time variables): dt_2012, dt_2013, dt_2014,dt_2015, dt_2016;

- share of foreign owners (Share FO), which corresponds to the share of foreign owners in the authorized capital of the enterprise (for $\mathrm{RO}$ (domestic) enterprises ShareFO=0, for enterprises in $\mathrm{FO}$ ShareFO $=1$, for enterprises in JO ShareFO is in the range from 0 to 1);

- ruble's depreciation - the ratio of the ruble-dollar exchange rate to the end of the current and the end of the previous year. If this ratio is greater than 1 , the ruble rate has decreased relative to the dollar. If this ratio is less than 1 , the ruble rate has increased relative to the dollar. The variables exhibited reasonable correlations (Table 2).

Table 2

Descriptive statistics and correlations

\begin{tabular}{|l|l|c|c|c|c|c|c|c|c|}
\hline & Variables & Mean & St. dev. & 1 & 2 & 3 & 4 & 5 & 6 \\
\hline 1 & $\begin{array}{l}\text { Size of the } \\
\text { enterprise }\end{array}$ & 20.72 & 1.51 & 1.00 & & & & \\
\hline 2 & $\begin{array}{l}\text { Fixed assets } \\
\text { share }\end{array}$ & 0.23 & 0.18 & $0.11^{* * *}$ & 1.00 & & & & \\
\hline 3 & $\begin{array}{l}\text { Current liquidity } \\
\text { ratio }\end{array}$ & 1.93 & 1.98 & $-0.11^{* * *}$ & $-0.15^{* * *}$ & 1.00 & & & \\
\hline 4 & dt_2012 & 0.20 & 0.40 & 0.00 & -0.01 & -0.03 & 1.00 & & \\
\hline 5 & $\begin{array}{l}\text { Ruble's } \\
\text { depreciation }\end{array}$ & 1.17 & 0.31 & -0.01 & 0.02 & $-0.06^{*}$ & $-0.37^{* * *}$ & 1.00 & \\
\hline 6 & ShareFO & 0.23 & 0.40 & $0.31^{* * *}$ & $0.14^{* * *}$ & 0.01 & 0.00 & 0.00 & 1.00 \\
\hline
\end{tabular}

For: ${ }^{* * *} \mathrm{p}<.001 .,{ }^{* *} \mathrm{p}<.01 .,{ }^{*} \mathrm{p}<.05 .$, and $\mathrm{p}<.10$.

\section{Models and estimation}

Given the multi-year nature of our data we needed to utilize panel data techniques to test our hypotheses.

Diagnosis of the panel model with control variables showed the following:

1) a simple regression model based on the method of least squares is estimated as not adequate, with preference being given to models with fixed effects based on Wald test statistic ( $\mathrm{pW}<<0.001)$, as well as models with random effects based on Breusch-Pagan test statistic (pB-P $<<0.001$ );

2) Hausman test statistic shows ( $\mathrm{chisq}=85.526, \mathrm{df}=3$, $\mathrm{p}$-value $<2.2 \mathrm{e}-16) \mathrm{pH}<<0.001$. Low p-values indicate a weak null hypothesis about the adequacy of the model with random effects, giving the advantage to models with fixed effects. Because of is, preference should be given to models with fixed effects.

Specifically, we utilized fixed effects estimation procedure. In all, we report four nested models.

Model 1 includes control variables.

Model 2 adds dummy time variable (dt_2012) to test Hypothesis 1.

Model 3 adds Ruble's depreciation variable, characterizing the effects of the depreciation of the ruble on enterprises in all forms of ownership to test Hypothesis 2.

Model 4 adds variable, characterizing the effects of the depreciation of the ruble on foreign-owned enterprises (Ruble's depreciation * ShareFO) to test Hypothesis 3.

To minimize the multicollinearity concerns, all predictor variables are standardized (Marquardt, 1980). 


\section{RESULTS AND DISCUSSION}

\section{Macroeconomic analysis}

The results of the analysis macro-economy indicators are shown in Fig. 1.

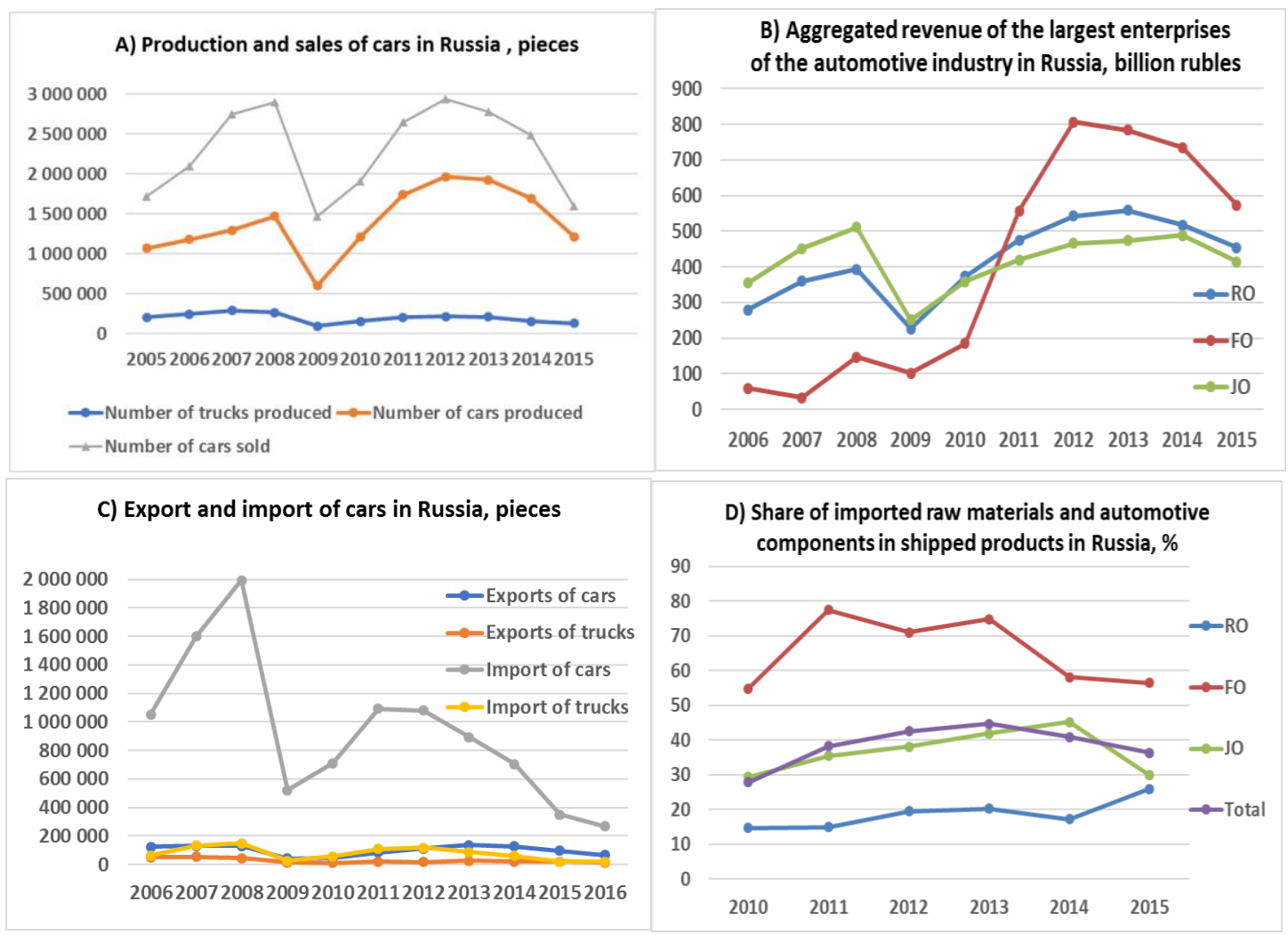

Figure 1. Trends in the development of the Russian automotive industry in terms of forms o ownership for the period 2006-2015

Source: Calculated by the authors according to (SPARK, 2017; FIRA 2017; Rosstat, 2017; UniSIS, 2017; Kulik, 2016)

The presented macroeconomic data allow us to draw the conclusions about the development of the automotive industry in Russia in accordance with the tested hypotheses and areas of our study:

1. The introduction of the industrial assembly regime contributed to the rapid development of FO enterprises in Russia, which are beginning to lead in revenue from 2011. The tightening of the industrial assembly regime did not affect the development of enterprises in FO in 2012. But crises have a strong negative impact on the development of enterprises of all forms of ownership (Fig. 1A, B).

2. The fact of "overheating" of the industry after post-crisis growth is revealed. The rapid growth in sales in 2010-2012 seems to have closed the pent-up demand for cars in 2009. Therefore, in 2013 there is already a decrease in sales. From 2014, the crisis begins, but there is some delay in the market reaction - the population is trying to buy cars at old prices and only after that the market collapses (Fig. 1A, B).

3. The effectiveness of the creation and development of enterprises in foreign and joint property is characterized both by positive and negative aspects of Russia.

Positive aspects are:

- organization of production in Russia of high-quality products that are highly valued by consumers (Fig. 1B); 
- reduction in imports especially in the crisis periods of 2009, 2015-2016, we hope that imports will not increase after the crisis 2015-2016 (Fig. 1C);

- high labour productivity at enterprises in FO, although it is largely due to the assembly nature of production (Spitsin et al., 2016).

Negative aspects are:

- low export volumes: export is not stable and surprisingly, it declined significantly in the 2015-2016 crisis, although the fall in the ruble should stimulate it (Fig. 1C);

- a high share of imported raw materials, which at enterprises in FO is $56 \%$ of the value of shipped products. This fact partially neutralizes the effects of the reduction of imports (replacing the import of finished cars for the import of auto components) (Fig. 1C, D);

- slowing the development of enterprises in $\mathrm{RO}$ and former Russian enterprises (Fig. 1B);

- low labour intensity and employment in enterprises in foreign ownership, a fall in employment in the industry, as shown in (Spitsin et al., 2016).

The four regression models formed above are presented in Table 3.

Regression results (fixed effects estimates, robust estimates) $*$

\begin{tabular}{|c|c|c|c|c|}
\hline & Model 1 & Model 2 & Model 3 & Model 4 \\
\hline Size of the enterprise & $\begin{array}{c}0.122^{* * *} \\
(0.013)\end{array}$ & $\begin{array}{c}0.123^{* * *} \\
(0.013)\end{array}$ & $\begin{array}{c}0.118^{* * *} \\
(0.013)\end{array}$ & $\begin{array}{c}0.120^{* * *} \\
(0.012)\end{array}$ \\
\hline Fixed assets share & $\begin{array}{c}0.001 \\
(0.008)\end{array}$ & $\begin{array}{c}0.002 \\
(0.008)\end{array}$ & $\begin{array}{c}0.004 \\
(0.008)\end{array}$ & $\begin{array}{c}0.002 \\
(0.007)\end{array}$ \\
\hline Current liquidity ratio & $\begin{array}{c}0.026^{* * *} \\
(0.005)\end{array}$ & $\begin{array}{c}0.028^{* * *} \\
(0.005)\end{array}$ & $\begin{array}{c}0.024 * * * \\
(0.005)\end{array}$ & $\begin{array}{c}0.022^{* * *} \\
(0.004)\end{array}$ \\
\hline dt_2012 & & $\begin{array}{c}0.020 * * * \\
(0.003)\end{array}$ & $\begin{array}{c}0.011 * * * \\
(0.003)\end{array}$ & $\begin{array}{c}0.010 * * * \\
(0.003)\end{array}$ \\
\hline Ruble's depreciation & & & $\begin{array}{c}-0.024 * * * \\
(0.003)\end{array}$ & $\begin{array}{c}-0.024 * * * \\
(0.003)\end{array}$ \\
\hline $\begin{array}{l}\text { Ruble's depreciation * } \\
\text { ShareFO }\end{array}$ & & & & $\begin{array}{c}-0.033 * * * \\
(0.003)\end{array}$ \\
\hline Intercept & $\begin{array}{c}-0.424 * * * \\
(0.070)\end{array}$ & $\begin{array}{c}-0.429 * * * \\
(0.068)\end{array}$ & $\begin{array}{c}-0.413^{* * *} \\
(0.067)\end{array}$ & $\begin{array}{c}-0.421 * * * \\
(0.063)\end{array}$ \\
\hline Overall R² (proj model) & 0.087 & 0.121 & 0.166 & 0.265 \\
\hline$\Delta \mathrm{R}^{2}$ (proj model) & - & 0.034 & 0.045 & 0.099 \\
\hline Fit statistics & $\mathrm{F}(3,1217)=21.42$ & $\begin{array}{c}\mathrm{F}(4,1216)= \\
34.36\end{array}$ & $\mathrm{~F}(5,1215)=39.2$ & $\mathrm{~F}(6,1214)=37.67$ \\
\hline $\mathrm{p}$ & $<0.001$ & $<0.001$ & $<0.001$ & $<0.001$ \\
\hline
\end{tabular}

Source: Calculated by the authors according to data (SPARK, 2017; FIRA 2017)

* Standard errors are in parentheses. For ${ }^{* * *} \mathrm{p}<.001,{ }^{*} \mathrm{p}<.01,{ }^{*} \mathrm{p}<.05$, and $. \mathrm{p}<.10$.

According regression results, Model 1 includes only control variables and fits the data adequately which is suggested by the test statistic $(p<.001)$ and explains about $8.7 \%$ of the variance in the industry profitability dynamics. Two of the control variables were significant at the conventional level. The scale effect of production is confirmed: profitability is higher for larger enterprises in the crisis period $(\beta=0.12$, $\mathrm{p}<.001)$. Also, we revealed positive influence of current liquidity on profitability in the crisis period $(\beta=$ 
$0.026, \mathrm{p}<.001)$. At the same time, the share of fixed assets in assets does not have a significant impact on the profitability of the automotive industry.

Model 2, (dt_2012) demonstrates an improvement in the model fit and explains $12.1 \%$ of variance in the industry profitability dynamics. Year dummy (dt_2012) emerges as a strong, positive predictor of the profitability dynamics in the industry $(\beta=0.02, \mathrm{p}<.001)$. This refutes Hypothesis 1 . Therefore, we have not identified that tightening of the industrial assembly regime in 2011 adversely affected the development of foreign-owned enterprises in Russia. On the contrary, enterprises of all forms of ownership showed maximum profitability in 2012. This conclusion is also confirmed by Fig. 1B.

Model 3 present another significant improvement in the model fit and explains $16.6 \%$ of variance in the industry profitability dynamics and thus increasing the predictive power of Model 2 by $4.4 \%$. Variable (Ruble's depreciation) shows a strong, negative affect the profitability of enterprises of all forms of ownership $(\beta=-0.024, \mathrm{p}<.001)$. This provides support to Hypothesis 2. Model 3 confirms that the depreciation of the ruble negatively affected profitability dynamics of automotive industry. This trend was especially strong during the crisis period, when the ruble rate was significantly reduced (Ruble's depreciation_2014 = 1.72, Ruble's depreciation_2015 = 1.3).

Finally, Model 4 (F-test, $\mathrm{p}<.001$ ) explains up to $26.5 \%$ of variance in the industry profitability dynamics - and additional 10\% improvement in R2 compared to Model 3. Variable (Ruble's depreciation * ShareFO) shows a strong, negative affect the profitability of foreign-owned enterprises $(\beta=-0.033, p<$ .001). This provides support to Hypothesis 3. Model 4 confirms that the depreciation of the ruble has a stronger negative impact on foreign-owned enterprises profitability dynamics in automotive industry. The other significant variables retain their influence in model 4 , but their $\beta$ coefficients decrease slightly.

The obtained results characterize certain patterns of behavior of foreign-owned enterprises in the automotive industry of countries with an unstable economy. Foreign owners try to avoid customs duties and get access to the market of such countries by implementing a scheme of large-scale industrial assembly. However, this option has minimal economic benefits for the host country. Their governments will seek to increase localization of production, integration into research and innovation chains with domestic enterprises and research institutes through the methods of regulation, and in the future - the transition to export of products. Moreover, the higher the capacity of the automobile market, the greater the regulatory control capacity of the government.

Russia in this regard is no exception. Foreign-owned enterprises in the automotive industry of Russia generate a number of positive effects in the economy (production of high-quality products based on modern technologies, reduction of imports of finished cars), but also lead to some negative results.

The most important negative aspects that need to be overcome are:

- low volumes of export of products in the automotive industry, which are significantly reduced during periods of crises;

- the high share of imported raw materials in the products of enterprises in FO.

However, the crisis period and sanctions imposed a number of distinctive features on this process.

In 2011, it was expected that the conditions of the industrial assembly regime would become much tougher, but against the background of the crisis and the decline in market capacity (Figure 1a), it was postponed several times. Thus, the crisis slowed the process of tightening the regime of industrial assembly. On the other hand, the conditions for Russia's accession to the WTO should significantly reduce the customs barriers for the import of finished cars. However, in the current situation, Russia, guided by sanctions, may not go on mitigating the customs regime.

Thus, enterprises in the FO and JO operating in the territory of Russia are likely to retain their customs privileges and advantages over foreign producers. At the same time, the intensity of state regulation (tightening of the assembly regime) is likely to be moderate in conditions of economic instability and 
unstable market capacity. The government will try to pursue its policy, but at the same time avoid closing large foreign productions in order to exclude the discontent of the population. At the same time, foreign companies can not be used in the sanctions war, as they represent different countries (the United States, EU countries, Korea, Japan, China, etc.), both supporting sanctions and not supporting.

We have identified the negative impact of the crisis (depreciation of the ruble against foreign currencies) on enterprises of all forms of ownership, and especially a strong negative impact - on foreignowned enterprises. Moreover, the specifics of the enterprises of the automotive industry in Russia lies in low volumes of exports and the use of imported components, which contributes to the creation of negative effects. However, there are a number of distinctive features:

1) Ruble's depreciation (calculated as the ratio of the ruble-dollar exchange rate to the end of the current and the end of the previous year) has a particularly strong negative impact on regression models, and the fact that the worst results (losses for most enterprises in the FO and JO) were fixed in 2014, when the volume of demand decreased slightly, and the average annual exchange rate of the ruble changed not much;

2) Despite the losses and depreciation of the ruble, foreign companies continue to operate in Russia and are in no hurry to localize production, although the benefits of the latter are obvious.

The second feature suggests that making a profit is not necessarily the goal of foreign-owned enterprises. Perhaps, it is more important for their owners to enter the Russian market without customs duties to supply their components.

\section{CONCLUSION}

The research initiates the following conclusions.

1. The adoption of the industrial assembly regime in 2005 was a serious incentive for the creation and development of enterprises in foreign ownership and the creation of new territorial centres of the automotive industry in Russia. However, intensive creation and advanced development of enterprises in FO occur, as a rule, only with the growing market: 2007, 2011-2012. Using regression analysis, we found that the tightening of the industrial assembly regime in 2011 did not have a negative impact on enterprises in FO in 2012.

2. The crisis periods have a strong negative impact on the revenue of enterprises by all forms of ownership. This influence is well modeled using a variable characterizing the change in the ruble / dollar exchange rate at the end of the year. Variable (Ruble's depreciation) shows a strong, negative affect the profitability of enterprises of all forms of ownership.

3. The depreciation of the ruble has a particularly negative impact on the profitability of foreign-owned enterprises (enterprises in FO and JO). Variable (Ruble's depreciation * ShareFO) shows a strong, negative affect the profitability of foreign-owned enterprises.

The effect of the change in the ruble exchange rate at the end of the year on the profitability of enterprises suggests, among other things, that the enterprises have foreign currency loans. The negative exchange rate differences of these loans led to the foreign-owned enterprise's losses in 2014.

\section{ACKNOWLEDGEMENT}

The research is conducted with financial support from Russian Foundation for Basic Research (RFBR) in the frames of scientific and research project of RFBR named "Dynamic modelling of Russian, foreign and joint industrial enterprises development in a situation of economic sanctions," project №. 17-0600584(a). The study of regional centres of car production and innovation activity was carried out with the support of Ministry of Education, Science and Technological Development, Republic of Serbia (Grant III 47007). 


\section{REFERENCES}

Adamowicz, M., \& Machla, A. (2016). Small and Medium Enterprises and the Support Policy of Local Government. Oeconomia Copernicana, 7(3), 405-437. doi: http://dx.doi.org/10.12775/OeC.2016.024

Atkinson, A.B., \& Stiglitz, J.E. (1980). Lectures on Public Economics. London, McGraw Hill.

Ayyagari, M., Beck, T., \& Demirguc-kunt, A. (2007). Small and medium enterprises across the globe. Small Business Economics, 29, 415-434. doi: http://dx.doi.org/10.1596/1813-9450-3127

Beck, T., Demirguc-Kunt, A., Martinez Peira, M.S. (2011). Bank financing for SMEs: evidence across countries and bank ownership types. Journal of Financial Services Research, 39, pp. 35-54. doi: 10.1007/s10693-010-0085-4

Berger, A.N., \& Udell, G.F. (2002). Small business credit availability and relationship lending: the importance of bank organizational structure. The Economic Journal, 112(477), 32-53. doi: 10.1111/1468-0297.00682

Berger, A.N., Goldberg, L.G., \& White, L.J. (2001a). The effects of dynamic changes in bank competition on the supply of small business credit. European Financial Review, 5, 115-139.

Berger, A.N., Klapper, L.F., \& Udell, G.F. (2001b). The ability of banks to lend to informationally opaque small business. Journal of Banking and Finance, 25, 2127-2167. doi: 10.1016/S0378-4266(01)00189-3

Berger, A.N., Klapper, L.F., Martinez-Peria, M.S., \& Zaidi. R. (2008). Bank ownership and banking Relationships. Journal of Financial Intermediation, 17, 37-62. doi: 10.1016/j.jfi.2006.11.001

Chang, C., Liao, G., Yu, X., \& Ni, Z. (2014). Information from the lending relationship: evidence from loan defaults in China. Journal of Money, Credit and Banking, 46(6), 1225-1257.

Clarke, G., Cull, R., Martinez Peria, M.S., Sanchez, S.M., (2005). Bank lending to small business in Latin America: Does bank origin matter? Journal of Banking Money, Credit, and Banking, 37, 83-118.

D’Aurizio, L., Oliveiro, T., \& Romano, L. (2015). Family firms, soft information and bank lending in a financial crisis. Journal of Corporate Finance, 33, 279-292. doi: http://dx.doi.org/10.1016/j.jcorpfin.2015.01.002

Detragiache, E., Tressel, T., \& Gupta, P. (2006). Foreign banks in poor countries: Theory and evidence. IMF Working Paper No. 18. International Monetary Fund, Washington DC.

Dolezal, J., Snajdr, J., Belas, J., Vincurova, Z. (2015). Model of the loan process in the context of unrealized income and loss prevention. Journal of International Studies, 8(1), 91-106. doi: 10.14254/2071-8330.2015/8-1/8

Dubravska, M., Mura, L., Kotulic, R., \& Novotny, J. (2015). Internationalization of Entrepreneurship-Motivating Factors: Case Study of the Slovak Republic. Acta Polytechnica Hungarica, 12(5), 121-133.

Fiserova, T., Teply, P., \& Tripe, D. (2015). The performance of foreign-owned banks in the host country economics. Prague Economic Papers, 24(5), 1-24. doi: 10.18267/j.pep.527

Gormley, S., Kanatas., G., \& Venezia, I. (2006). Bank competition in developing countries: does foreign bank entry improve credit access? Mimeo. MIT.

Jimenez, G., Salas, V., Saurina, J. (2006). Determinants of collateral. Journal of Financial Economics, 81, 255-281. doi: 10.1016/j.jfineco.2005.06.003

Kljucnikov A., Belas, J., Kozubikova, L., \& Pasekova P. (2016).The Entrepreneurial Perception of SME Business Environment Quality in the Czech Republic. Journal of Competitiveness, 8(1), 66-78.

La Porta, R., Lopez-de-Silances, F., \& Shleifer, A. (2002). Government ownership of commercial banks. Journal of Finance, 57(1), 265-301. doi: 10.1111/1540-6261.00422

Menkhoff, L., Neuberger, D., \& Rungruxsirivorn, O. (2012). Collateral and its substitutes in emerging markets lending. Journal of Banking and Finance, 36, 817-834.

Mian, A. (2003). Foreign, private domestic, and government banks: New evidence from emerging markets. University of Chicago, Mimeo.

Mian, A. (2006). Distance constraints: the limits of foreign lending in poor economics. Journal of Finance, 61(3), 14651505. doi: 10.1111/j.1540-6261.2006.00878.x

Nguyen, S., \& Wolfee, S. (2016). Determinants of successful access to bank loans by Vietnamese SMEs: new evidence from the red river delta. Journal of Internet Banking and Commerce, 21(1), 1-23.

Afanasyev, S.A. (2014). Automotive industry making-up in developing countries, Rossiyskoe predprinimatelstvo, 10(256) 123-136.

Akimkina, D.A. (2014). Problems of the strategy for the development of the automotive industry and the ways of their solutions. Finansovaya analitika: Problem I resheniya, 7, 44-54.

Anwar, S., \& Sun, S. (2015). Can the presence of foreign investment affect the capital structure of domestic firms?, Journal of Corporate Finance, 30, 32-43. 
Baronina, Y. (2016). Foreign Investment into Russian Automotive Industry, Mirovaya ekonomika $i$ mezhdunarodnye otnosheniya, 60(6), 61-69.

Basti, E., Bayyurt, N., \& Akin, A. (2015). A Comparative Performance Analysis of Foreign and Domestic Manufacturing Companies in Turkey. European Journal of Economic and Political Studies website. Retrieved from http://ejeps.fatih.edu.tr/docs/articles/136.pdf.

Buckley, P., Wang, C., \& Clegg, J. (2007). The impact of foreign ownership, local ownership and industry characteristics on spillover benefits from foreign direct investment in China, International Business Review, 16, 142-158.

Bulletin of socio-economic crisis in Russia. Cars market. (May 2016). Retrieved from http://ac.gov.ru/files/publication/a/9154.pdf

Chan, T. T., \& Hoshgiyafeh A. R. M. (2014). The strategy of forming the automotive industry in developing countries, Iqvestiya Moskovskogo gosudarstvennogo tehnicheskogo universiteta (MAMI), 5(22), 42-47, Retrieved from https:/ / elibrary.ru/item.asp?id $=23028544$

Chayawisan, N. (2015). The interaction between domestic and foreign direct investment in Thailand, British Journal of Economics, Management and Trade, 9(2), 1-6.

Chatterjee, S. (2018). The Impact of Working Capital on the Profitability: Evidence from the Indian Firms. SSRN Electronic Journal. Elsevier BV, 2012. Retrieved March 11, 2018 from http://dx.doi.org/10.2139/ssrn.2125228.

Chen, W. (2011). The effect of investor origin on firm performance: Domestic and foreign direct investment in the United States, Journal of International Economics, 83(2), 219-228.

Chen, Z., Ge, Y., \& Lai, Hn. (2011). Foreign Direct Investment and Wage Inequality: Evidence from China, World Development, 39(8), 1322-1332.

Chuprov, A. (2018). The Russian car market in 2017 remained on the fifth place in Europe - 01.01.2018. Retrieved from https://www.autostat.ru/news/32730/

Dachs, B., \& Peters, B. (2014). Innovation, employment growth, and foreign ownership of firms: A European perspective. Research Policy, 43, 214-232.

Efremova, A.D. (2015). Trends in the automotive industry in Russia and abroad. Sovremennaya nauka: Aktualnyie problemyi i puti ih resheniya, 29(15), 49-53.

Eurostat. (2015). Retrieved from http://ec.europa.eu/eurostat.

Fava V., \& Luminita, G. (2017). East-West cooperation in the automotive industry: Enterprises, mobility, production. The Journal of Transport History, 38(1), 11-19.

Firat, D., \& Li, S. (2016). Total Factor Productivity, Foreign Direct Investment, and Entry Barriers in the Chinese Automotive Industry. Emerging Markets Finance and Trade, 52(2), 302-321.

Girma, S., Gong, Yu., \& Görg, G. (2009). What Determines Innovation Activity in Chinese State-owned Enterprises? The Role of Foreign Direct Investment. World Development, 37(4), 866-873.

Godlewska-Majkowska, H., \& Komor, A. (2017). Regional Strategic Groups as a Tool of Enterprises Localization Analysis on Automotive Industry in the European Union. Engineering Economics, 28(1), 35-46.

Grubisic, Z., Zaric, S., \& Vukovic, D. (2011). FDI Inflow in see Countries and its Consequences in the Context of the Financial Crisis. Finance and the Performance of Firms in Science, Education, and Practice. Tomas Bata University in Zlin, Faculty of management and economics, Czech Republic. (edt.) Drahomira Pavelkova, (Proceedings paper), 116-129.

Habrosh, A.A. (2017). Impact of Cash Flow, Profitability, Liquidity, and Capital Structure Ratio on Predict Financial Performance. Advanced Science Letters, 23(8), 7177-7179. Retrieved from http://dx.doi.org/10.1166/asl.2017.9322.

Information resource FIRA, Russia (2017). Retrieved from https://www.fira.ru/

Information resource SPARK, Russia (2017). Retrieved from http://www.spark-interfax.ru/

Kochetkov, D. M., Larionova, V. A., \& Vukovic D. B. (2017). Entrepreneurial Capacity of Universities and Its Impact on Regional Economic Growth. Ekonomika regiona [Economy of Region], 13(2), 477-488. doi 10.17059/2017-2-13

Komissarova, J. (2015). French automobile industry. Mirovoe i natsionalnoe hozyaystvo, 3(34), 1. Retrieved from https:/ / elibrary.ru/item.asp?id=25437134

Kulik, I. (2016). Statistics of sales of cars in Russia - what models and brands are purchased by our compatriots?, Ilya Kulik blog [in Russian]. Retrieved from http://kulikavto.ru/kuplya-prodazha/statistika-prodazh-avto-v-rossiipo-godam-i-modelyam.html

Kurganov, Y.A. (2015). Current trends and conditions of production cooperation development in Russia's automotive industry. Rossiyskiy vneshneekonomicheskiy vestnik, 10, 96-103. 
Lynch, T.M. (2002). Leveraging Capabilities: Models of Foreign Production in the Taiwanese Automotive Industry. In: Horaguchi H., Shimokawa K. (eds) Japanese Foreign Direct Investment and the East Asian Industrial System. Springer, Tokyo.

Marquardt, D. (1980). You should standardize the predictor variables in your regression models. Journal of the American Statistical Association, 75, 87-91.

Murakami, Yu. (2007). Technology spillover from foreign-owned firms in Japanese manufacturing industry. Journal of Asian Economics, 18, 284-293.

Ovchinnikova, A.V., \& Karpova, M.A. (2015). Application of the theory of industrial markets to study the current trend in the automobile industry development. Vestnik Udmurtskogo universiteta, Seryia Ekonomika I Pravo, 2-3, 5562.

Pasko, A.V. (2014). Competitiveness of the Russian automotive industry on the background of world automobile development key trends. Novyiy vaglyad. Mez̧bdunarodnyiy nauchnyiy vestnik. Retrieved from https://elibrary.ru/item.asp?id $=21719953$

Pavlinek, P. (2017). Dependent Growth: Foreign Investment and the Development of the Automotive Industry in East-Central Europe, Springer International Publishing.

Podhalyuzina, V. A. (2015). On measures to increase the flow of investment into the Russian automotive industry. Vestnik Moskovskogo avtomobilno-dorozhnogo gosudarstvennogo tekhnicheskogo universiteta (MADI), 1(40), 63-68.

Russian automotive production localization. (2014). Auto business journal website. Retrieved from http://automediapro.ru/articles/analitika/lokalizatsiya-vypuska-avtomobilej-v-rossii/

Russian Federation. (2017). Russian Federal State Statistics Service [Rosstat]. Retrieved from http://www.gks.ru/wps/wcm/connect/rosstat main/rosstat/en/main/

Spitsin, V.V., Mikhalchuk, A.A., Spitsina, L.Y., Tyuleneva, N.A., \& Novoseltseva, D.A. (2016). Social results of domestic and Foreign firms: Case Manufacture of transport equipment in Russia. International Journal of Economics and Financial Issues, 6(1), 147-153.

Sun, W., Yang, X., \& Xiao, G. (2015). Understanding China's High Investment Rate and FDI Levels: A Comparative Analysis of the Return to Capital in China, the United States, and Japan, United States International Trade Commission website, Retrieved from http://www.usitc.gov/journals/06 SunYangXiao UnderstandingInvestmentFDI.pdf.

Szkorupová, Z. (2015). Relationship between Foreign direct investment and domestic investment in selected countries of central and Eastern Europe. Procedia Economics and Finance, 23, 1017-1022.

Unified Interdepartmental Statistical Information System (UniSIS), Russia. (2017). Retrieved from https://fedstat.ru/.

Vaicondam, Y., \& Ramakrishnan, S. (2018). Capital Structure and Profitability across Malaysian Listed Firms. Retrieved from http://www.ingentaconnect.com/content/asp/asl/2017/00000023/00000009/art00240;jsessionid=dneb4bc f7b0c0.x-ic-live-01 (accessed 12 March 2018).

Villarreal, A., \& Sakamoto, A. (2011). Bringing the firms into globalization research: The effects of foreign investment and exports on wages in Mexican manufacturing firms. Social Science Research, 40(3), 885-901.

Volgina, N.A., \& Vozmilova, S.S. (2015). Global value chains in the automotive industry: modern trends. Vestnik Rossiyskogo universiteta druzhby narodov. Seriya Ekonomika, 2, 36-48.

You, K., \& Solomon, O.H. (2015). China's outward foreign direct investment and domestic investment: An industrial level analysis. China Economic Review, 34, 249-260.

Zhang, H. Y., \& van den Daniel, B. (2000). The Restructuring of the Chinese Automotive Industry: the Role of Foreign Direct Investment and the Impact of European Multinational Enterprises. In International Business (pp. 290-312). Palgrave Macmillan, London. 